\title{
凍結防止剂によるスケーリング現象に及ぼす冷却最低温度の影響と スケーリング温度
}

\author{
田中舘悠登 ${ }^{* 1}$ 羽原俊祐 ${ }^{* 2}$ 小山田哲也 ${ }^{* 2}$ 我満俊文 ${ }^{* 3}$
}

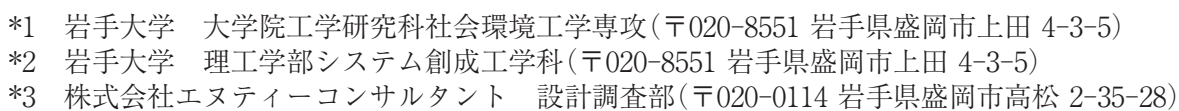

要旨：凍結防止剂使用時にコンクリートのスケーリング劣化が促進することから、ソルトスケーリングと 認識されている。これまでのスケーリング劣化メカニズムの検討では、 $-5 \sim-10{ }^{\circ} \mathrm{C}$ 温度域以下ではス ケーリングが激しく、それ以上の温度域ではスケーリングが生じないことを見出した。本研究ではー5〜 $-10{ }^{\circ} \mathrm{C}$ 温度域において、ソルトスケーリングに及ぼす冷却最低温度と $\mathrm{NaCl}$ 水溶液の濃度との関係を 詳細に検討した。スケーリングが発生する最高温度をスケーリング温度と定義した。スケーリング温度は $\mathrm{NaCl}$ 水溶液の濃度によって異なり、 $\mathrm{NaCl}$ 水溶液の凝固点よりも $5 \sim 6{ }^{\circ} \mathrm{C}$ 程度低いことがわかった。ブラ イン水(塩水)の凍結時の挙動がスケーリングに関係している可能性があることを示した。

キーワード：凍害、凍結融解、ソルトスケーリング、凍結防止剤、小片試験方法、冷却温度

\section{1. はじめに}

スケーリングは、積雪寒冷地域における凍結融解作用 によるコンクリートの劣化現象である。1991 年に「ス パイクタイヤ粉じんの発生の防止に関する法律」が施行 されて以来、冬期の安全交通のため、 $\mathrm{NaCl}$ 等の凍結防 止剂の散布が年々増大している。凍結防止剤の散布量の 増加に伴い道路におけるコンクリート構造物のスケーリ ング劣化が顕著になり、スケーリング劣化の割合が著し くなっている。この劣化現象はソルトスケーリングとも 呼ばれている。

スケーリング劣化についてこれまで多くの研究がなさ れ、様々な劣化メカニズムが提案されてきた。劣化メカ ニズムは、社団法人日本コンクリート工学協会編「コン クリートの凍結融解抵抗性の評価方法に関する研究委員 会報告書 (2008)」において、コンクリート飽水度の上 昇 $^{1,2)}$ 、表層の押し上げ現象 ${ }^{3,4)}$ 、表層のクリープ現象 ${ }^{5)} 、$ 熱衝撃 ${ }^{6)}$ 、化学作用 ${ }^{3)}$ に整理されている。現状では、こ れらの劣化メカニズムのいくつかが複合的に作用するこ とで劣化が発生、進行すると考えられている。複合的に 作用するため、詳細な劣化メカニズムは不明である。そ のため、すべての劣化を包括した詳細な劣化メカニズム の構築が必要とされている。

本研究室では、これまで劣化メカニズムの解明のため、 冷却最低温度と $\mathrm{NaCl}$ 水溶液の濃度及びモルタル配合 が、ソルトスケーリング劣化に与える影響について検討 した。その中の結果として、冷却最低温度とスケーリン グ抵抗性の関係を Fig. 17)に示す。SDI はスケーリング
抵抗性を示し、值が高いほどスケーリング抵抗性が高く、 60 以上で極めてスケーリング耐久性が高いことを示す。 真水の場合では凍結融解サイクルが 10 回ではスケーリ ングは発生せず、濃度 1.0 及び $3.0 \%$ の $\mathrm{NaCl}$ 水溶液 の場合、冷却最低温度が-10 ${ }^{\circ} \mathrm{C}$ 以下の範囲ではスケー リングが激しい。 $-10 \sim-40{ }^{\circ} \mathrm{C}$ 範囲では劣化度の相 違は小さい。 $-5 \sim-10{ }^{\circ} \mathrm{C}$ 温度域では温度により劣化 度は大きく異なり、 $-5{ }^{\circ} \mathrm{C}$ 以上ではスケーリングが発生 しないことを見出した。このことから、温度により劣化 度が大きく異なる $-5 \sim-10{ }^{\circ} \mathrm{C}$ 温度域にスケーリング 発生の有無が存在し、この温度域の挙動を確認すること により、スケーリング劣化のメカニズム解明の手がかり が得られると考える。

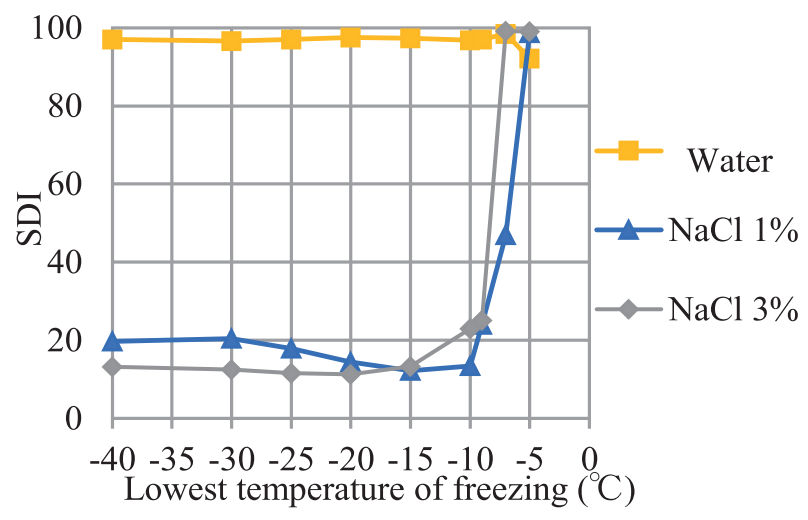

Fig. 1 SDI with different lowest temperature ${ }^{7)}$ 
そこで本研究はスケーリング劣化の劣化メカニズムの 解明を目的とし、小片凍結融解試験法を用いて、冷却最 低温度がー5〜 - $10{ }^{\circ} \mathrm{C}$ の温度域において、温度を $1{ }^{\circ} \mathrm{C}$ 刻みに冷却最低温度を変更し、また $0.1 、 0.5 、 1.0$ 及 び $3.0 \%$ と $\mathrm{NaCl}$ 水溶液の濃度を変えて、ソルトスケー リング劣化に与える影響について検討した。

\section{2. 実験概要}

\section{1 使用材料及びモルタル配合}

ここでは、既往の研究 ${ }^{7)}$ において冷却最低温度の影響 を検討したモルタルと同一配合のモルタル試料を作製し た。モルタル配合を Table 1 に示す。セメントは市販 の普通ポルトランドセメント (密度 : $3.15 \mathrm{~g} / \mathrm{cm}^{3}$ )を使用 し、細骨材は $2.5 \mathrm{~mm}$ 篩を通過した表乾状態の盛岡市黒 川産砕砂 (表乾密度 : $2.80 \mathrm{~g} / \mathrm{cm}^{3}$ )を用いた。 $\mathrm{AE}$ 剂は使 用せず、NonAE モルタルとした。

供試体は $40 \times 40 \times 160 \mathrm{~mm}$ の角柱供試体を作製し、 1 日型枠内で初期養生した後、打設後に材齢 28 日まで 水中養生を行った。

\section{2 スケーリング評価試験}

提案した小片凍結融解試験法 ${ }^{8,9)}$ に従い、ソルトスケー リング抵抗性の評価方法を実施した。湿式ダイヤモンド カッターを用いて、養生終了後の角柱供試体から 1 辺 験片 3 粒を 1 組とし、試験片 1 組の質量と $\mathrm{NaCl}$ 水溶 液との質量比を $1: 10$ とし、試験片を $\mathrm{NaCl}$ 水溶液に 浸漬させ凍結融解試験を実施した。試験条件を Table 2 に示す。冷却最低温度は、 $-5 \sim-10{ }^{\circ} \mathrm{C}$ 範囲において $1{ }^{\circ} \mathrm{C}$ 間隔で設定し、センサー式温度計を用い、設定の温 度と相違のないことを確認した。 $\mathrm{NaCl}$ 水溶液は濃度 0.1 、 0.5、1.0 及び $3.0 \%$ に設定した。1 日 1 サイクルの凍 結融解(凍結 16 時間、融解 8 時間)を与えた。所定のサ イクル終了後、試験片と $\mathrm{NaCl}$ 水溶液を分離し、試験片 を $40{ }^{\circ} \mathrm{C}$ で 24 時間乾燥させ、 $2.5 \mathrm{~mm}$ ふるい上に留まっ た質量を測定した。試験前後の質量から質量残存率を求 めた。質量残存率を元にスケーリング耐久性指標 (SDI) を算出した。SDIの計算は次の通りである。

$$
\mathrm{SDI}=\text { 質量残存率 }(\%)
$$

質量残存率が $90 \%$ 未満の場合

$$
\mathrm{SDI}=\mathrm{P} \times \mathrm{N} / \mathrm{M}
$$
が $8 \mathrm{~mm}$ の立方体を切り出し、これを試験片とした。試

$$
\begin{aligned}
\mathrm{P}= & 90(\%) \\
\mathrm{N}= & \text { 質量残存率が } \mathrm{P} \text { のときのサイクル数 }(\text { 回 }) \\
\mathrm{M}= & \text { 試験終了を予定しているサイクル数 }(\text { 回 }) \\
& (\text { 本報告の場合 } \mathrm{M}=10)
\end{aligned}
$$

既往の研究 ${ }^{8)}$ ではスケーリング抵抗性の評価のため、 SDI の基準の質量残存率を $60 \%$ としたが、本研究では スケーリング発生の有無を評価するため $90 \%$ とした。 なお、この小片凍結融解試験方法は、ASTM C 672 法 など他のソルトスケーリング評価試験方法と比較検討し

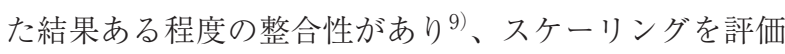
する上では有効であることを確認している。

\section{3. 実験結果及び考察}

\section{1 小片凍結融解試験結果}

凍結融解サイクル終了後の $2.5 \mathrm{~mm}$ 篩上の質量残存率 の結果を Fig. 2 に示す。 $\mathrm{NaCl}$ 水溶液の濃度ごとに、冷 却最低温度の違いによる質量残存率の推移を示す。各濃 度における冷却最低温度の影響を質量残存率の推移から 評価する。なお、真水では、 $-20{ }^{\circ} \mathrm{Cにおいて} 10$ サイ クルでも質量残存率が $100 \%$ 程度で、スケールングの 発生は認められなかった。

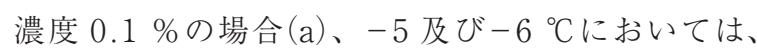
10 サイクルでは質量残存率が $90 \%$ 以下になる。一方、 $-7{ }^{\circ} \mathrm{C}$ 以下については、 5 から 10 サイクルでの質量残 存率の低下が著しく、このサイクルの間にスケーリング が進行したことがわかる。

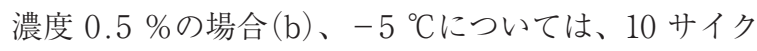
ルでも質量残存率が 90 \%以上を保持し、スケーリング

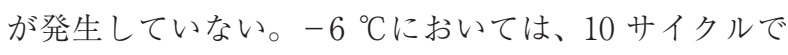
質量残存率が 80 以上であり、スケーリングは発生する が劣化は軽微であることがわかる。一方、 $-7{ }^{\circ} \mathrm{C}$ 以下に ついては、5 から 10 サイクルでの質量残存率の低下が 著しく、このサイクルの間にスケーリングが進行したこ とがわかる。

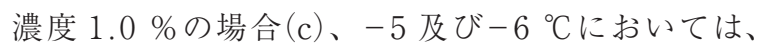
質量残存率が $100 \%$ 程度でスケーリングが発生してい

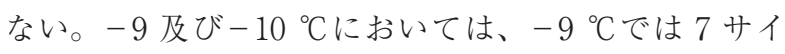
クル、 $-10{ }^{\circ} \mathrm{C}$ では 5 サイクル時に質量残存率が $10 \%$ 程度であり、スケーリングが激しいことがわかる。 -7

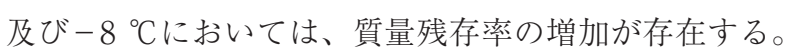
小片凍結融解試験法は、ASTM C 672 法のように $1 つ$ の供試体を継続的に観察する試験ではないため、試験片

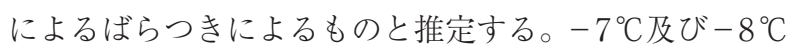
での質量残存率の低下があるため、これらの温度でもス

Table 2 Condition of experimental

\begin{tabular}{|c|c|}
\hline Type of cement & Ordinary Portland Cement \\
\hline Source of aggregate & Kurokawa, Morioka \\
\hline $\mathrm{w} / \mathrm{c}$ & 0.5 \\
\hline $\mathrm{s} / \mathrm{c}$ & 2.5 \\
\hline
\end{tabular}

\begin{tabular}{|l|l|}
\hline Lowest temperature $\left({ }^{\circ} \mathrm{C}\right)$ & $-5,-6,-7,-8,-9,-10$ \\
\hline $\begin{array}{l}\text { Concentration of } \mathrm{NaCl} \\
\text { solution }(\%)\end{array}$ & $0.1,0.5,1.0,3.0$ \\
\hline
\end{tabular}




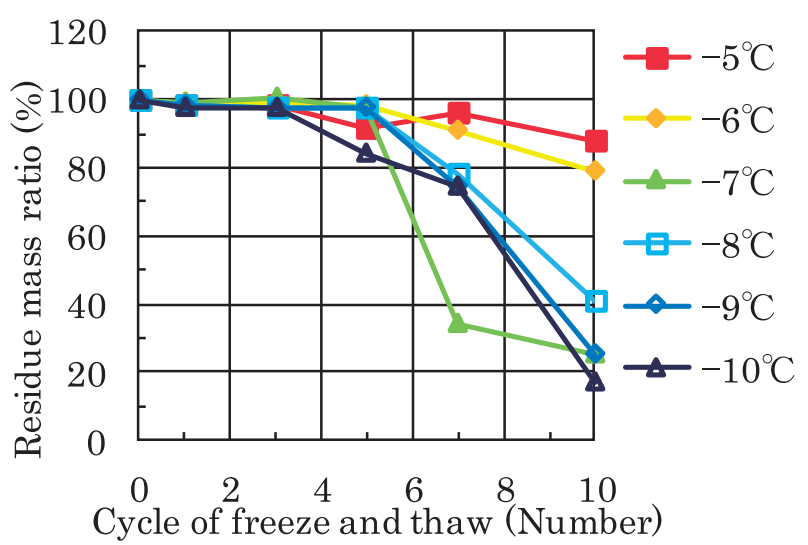

(a) Concentration of $\mathrm{NaCl}$ solution : $0.1 \%$

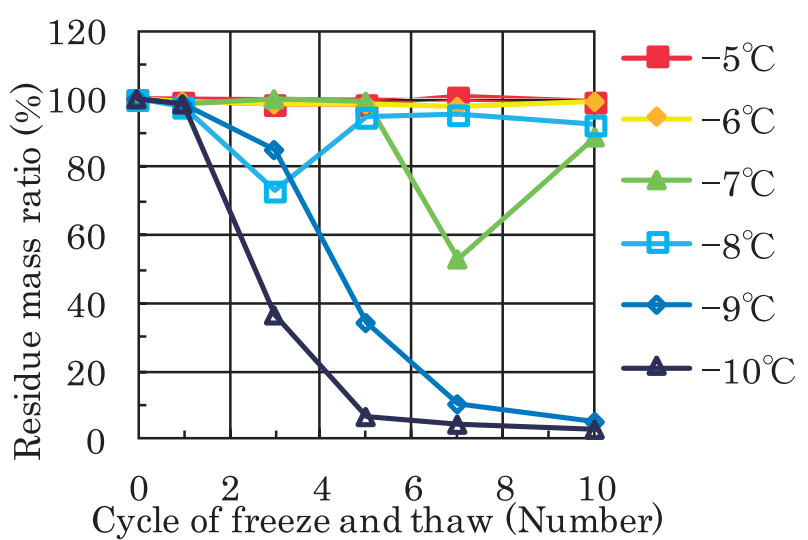

(c) Concentration of $\mathrm{NaCl}$ solution : $1.0 \%$

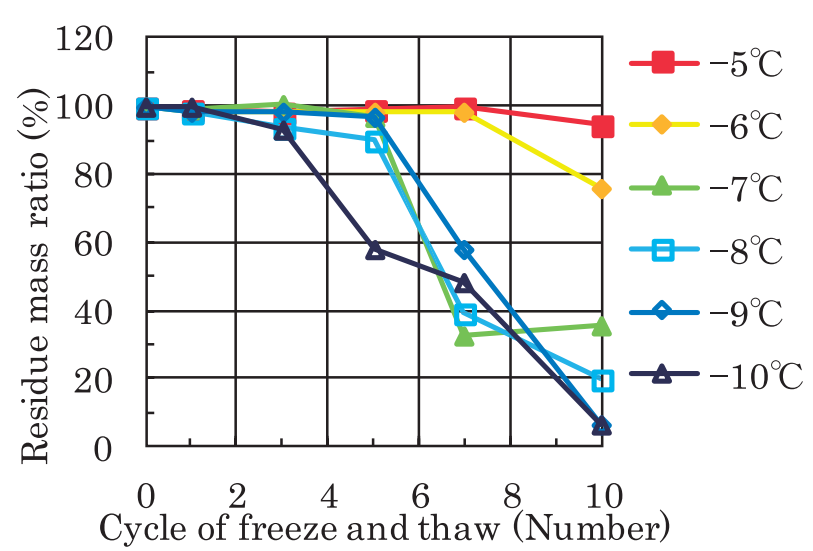

(b) Concentration of $\mathrm{NaCl}$ solution : $0.5 \%$

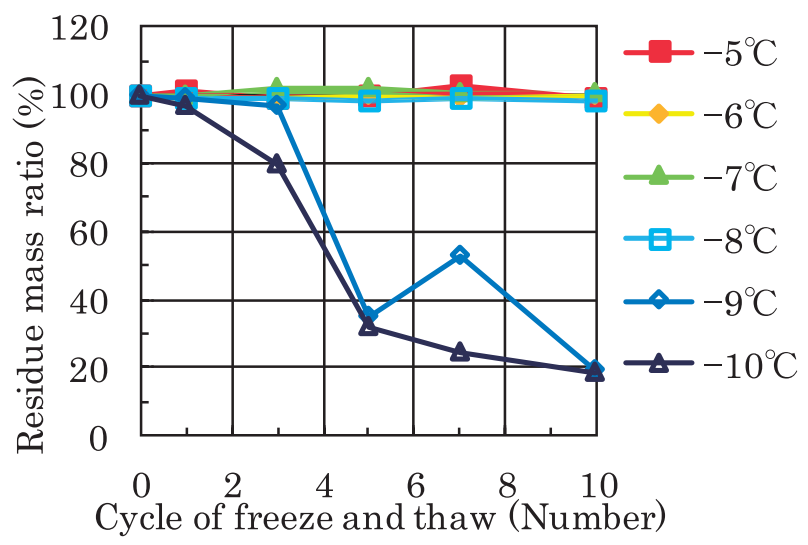

(d) Concentration of $\mathrm{NaCl}$ solution : $3.0 \%$

Fig. 2 Residue mass ratio(\%) of specimens with different lowest temperature of freezing

ケーリングが生じると推定する。

濃度 $3 \%$ の場合 $(\mathrm{d}) 、-8{ }^{\circ} \mathrm{C}$ 以上においては、質量残 存率が $100 \%$ 程度でスケーリングが発生していない。

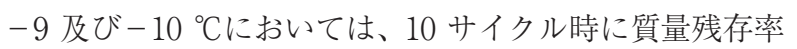
が 20 \%程度であり、スケーリングが激しいことがわかる。

10 サイクルでの質量残存率 $90 \%$ 以下の場合にスケー リングが生じているとすると、0.1％では-5 ${ }^{\circ} \mathrm{C} 、 0.5 \%$ では- $6{ }^{\circ} \mathrm{C} 、 1.0 \%$ では-7、- $8{ }^{\circ} \mathrm{C}$ 付近、 $3 \%$ では $-9{ }^{\circ} \mathrm{C}$ と、 $\mathrm{NaCl}$ 水溶液の濃度で異なるが、冷却最低温度があ る温度以下の場合にスケーリングが発生することがわ かった。その温度は、 $\mathrm{NaCl}$ 水溶液の濃度が高くなるほ ど低くなる傾向にある。このことから、スケーリング劣 化は、劣化発生の温度の閾值があると考えられる。本研 究では、劣化が発生する温度の閾值をスケーリング温度 と定義する。その温度以上の高い温度ではスケーリング は発生しないが、その温度以下の低い温度ではスケーリ ングが発生する。スケーリング温度は $\mathrm{NaCl}$ 水溶液の濃 度によって異なり、濃度が高くなるほどスケーリング温 度は低温になる傾向がある。

次に試験片の形状観察を行う。これまでの研究 ${ }^{8)}$ り、スケーリングが発生する場合、サイクルの進行とと もに試験片の面及び隅角部から剥離するため、試験片は
球状になる。さらにスケーリングが進行すると、試験片 は粒状になる。また、スケーリングは、骨材とセメント ペーストとの界面に存在する遷移帯部にスケーリングの 原因となるひび割れが生じるため、セメントペーストが 骨材から剥離し、セメントペーストと骨材が分離する。 Fig. 3 に 10 サイクル終了後の試験片の形状観察を示す。 濃度 $0.1 \%$ の場合、すべての温度でスケーリングが生じ、 特に- $7{ }^{\circ} \mathrm{C}$ 以下で、試験片が粒状になり原形を留めてお らずスケーリングが進行していることがわかる。濃度 $0.5 \%$ の場合、すべての温度でスケーリングが生じてい

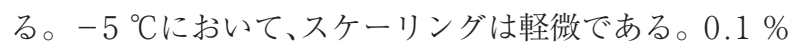
と同様に $-7{ }^{\circ} \mathrm{C}$ 以下での劣化が激しい。濃度 $1.0 \%$ の 場合、 -5 及び $-6{ }^{\circ} \mathrm{C}$ ではスケーリングしておらず、 $-9{ }^{\circ} \mathrm{C}$ 以下でスケーリングが激しいことがわかる。濃度 $3.0 \%$ の場合、 $-8{ }^{\circ} \mathrm{C}$ 以上ではスケーリングが発生せず、 $-9{ }^{\circ} \mathrm{C}$ 以下でスケーリングが激しい。

形状観察においても、スケーリング温度付近でスケー リングの発生の有無で分かれており、スケーリング温度 の存在を確認することができる。また、 $\mathrm{NaCl}$ 水溶液濃 度が高くなるほどスケーリング温度が低くなることが確 認できる。

スケーリング温度について定量的に示すため、10 サ 


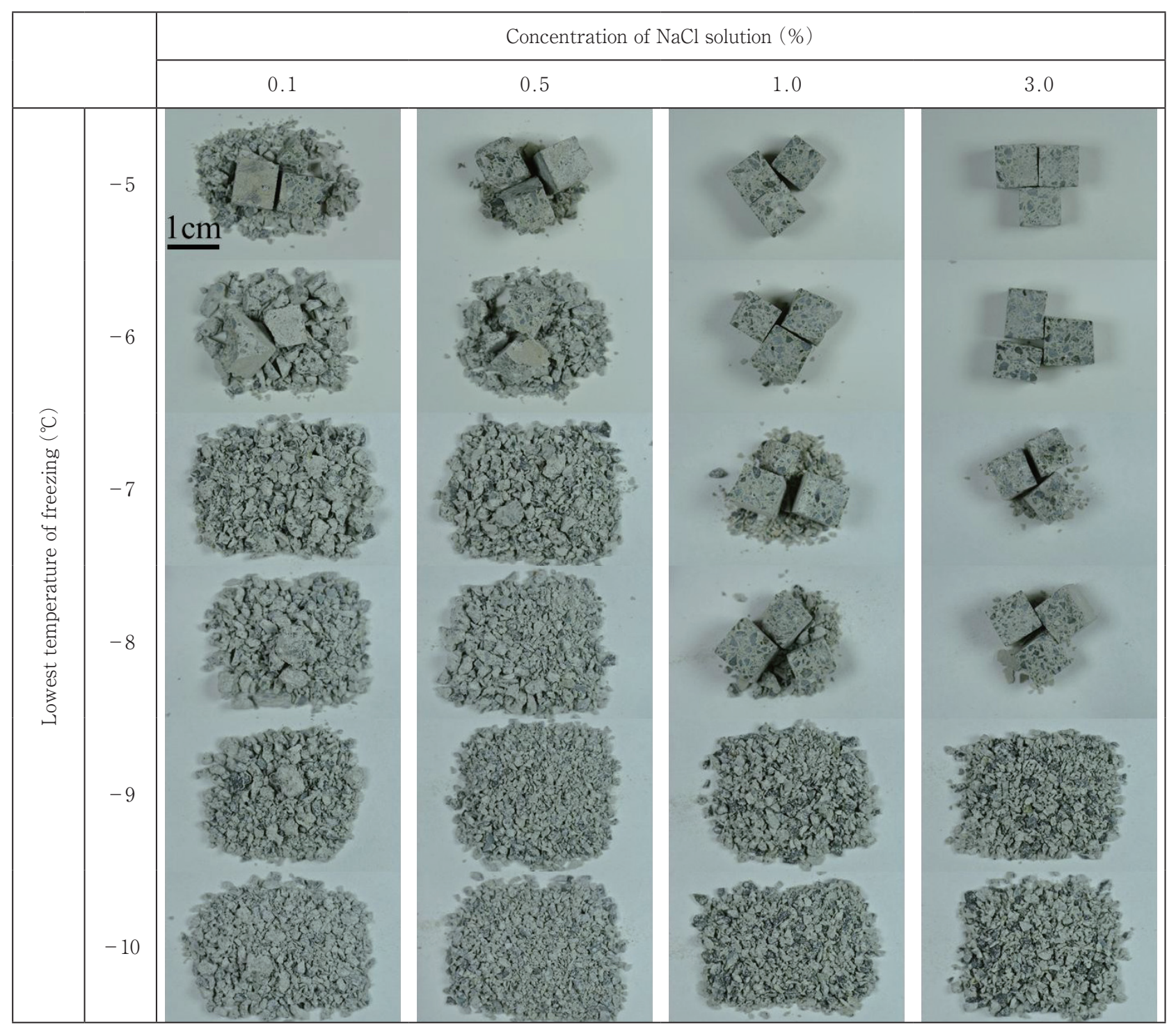

Fig. 3 Appearance of specimens after 10 cycles of freeze and thaw

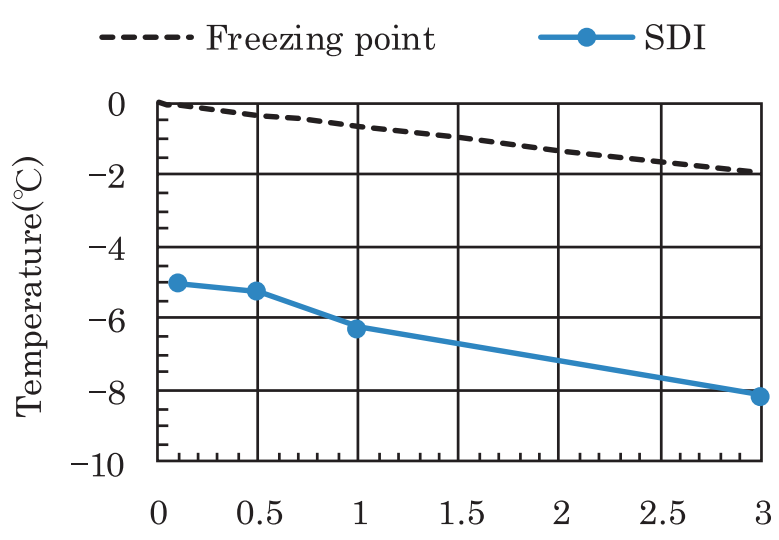

Concentration of $\mathrm{NaCl}$ solution (\%)

Fig. 4 Salt scaling temperature with concentration of $\mathrm{NaCl}$ solution (\%)

イクルを基準としたスケーリング耐久性指数 (SDI)を用 いて検討する。SDI は質量残存率の推移から、スケー
リングの劣化速度を定量的に示す指標であり、スケーリ ングの進行度を比較するのに有効な指標である。ここで は、 $\mathrm{NaCl}$ 水溶液の濃度ごとに各泠却最低温度について SDI を算出し、算出したSDI より各濃度に执いて SDI が 90 になる温度を算出し、この温度をスケーリング温 度とした。濃度 $0.1 \%$ に扔いて、すべての冷却最低温 度の SDI が 90 以下であるため、濃度 $0.1 \%$ のスケー リング温度を $-5{ }^{\circ} \mathrm{C}$ とた。 $\mathrm{NaCl}$ 水溶液の濃度とスケー リング温度の関係を Fig. 4 に示す。 $\mathrm{NaCl}$ 水溶液の凍結 では $\mathrm{Na}^{+}$及び $\mathrm{Cl}^{-}$の存在により凝固点降下が生じ、濃 度によりこれが異なり、凝固点降下がスケーリング温度 に影響すると考えられるため、 $\mathrm{NaCl}$ 水溶液の凝固点を 破線で示した。既往の研究 7 より真水ではスケーリング が発生しないため、真水のスケーリング温度は存在し ない。SDIにより求めたスケーリング温度は、0.1\%で $-5{ }^{\circ} \mathrm{C} 、 0.5 \%$ \% $-5.3{ }^{\circ} \mathrm{C} 、 1.0 \%$ で $-6.3{ }^{\circ} \mathrm{C} 、 3.0 \%$ でー8.1 ${ }^{\circ} \mathrm{C}$ をして打り、質量残存率及び形状観察の結 果を反映している。各濃度のスケーリング温度は、その 


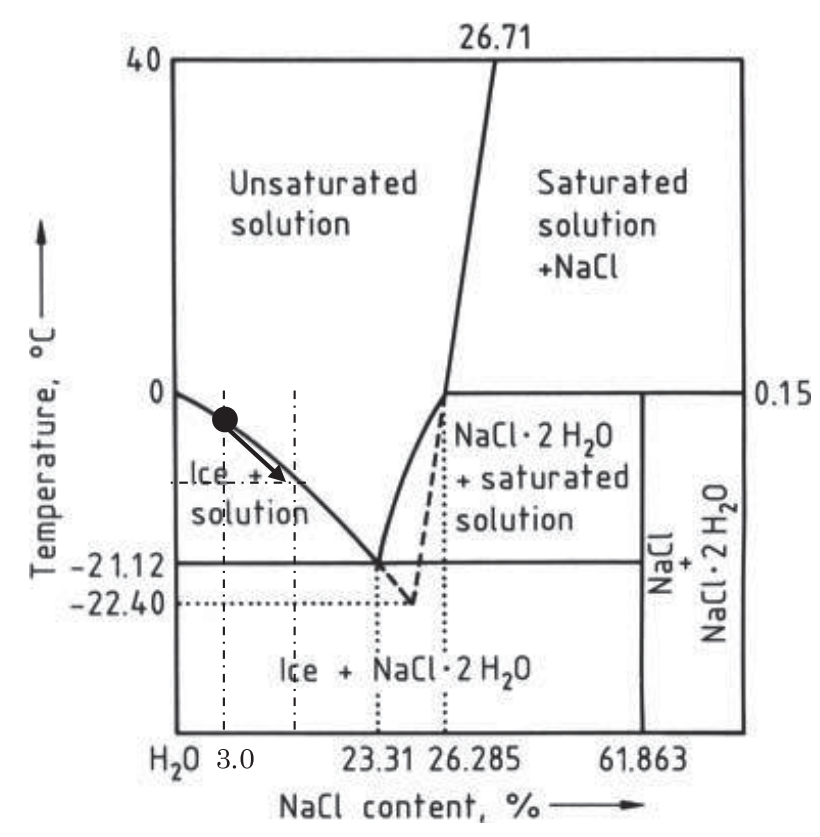

Fig. 5 Phase diagram of $\mathrm{H}_{2} \mathrm{O}-\mathrm{NaCl}$ system (schematic, not to scale) ${ }^{10)}$

濃度の凝固点よりも低い值を示す。また、凝固点とス ケーリング温度との温度差は、 $0.1 \%$ で $4.9{ }^{\circ} \mathrm{C} 、 0.5 \%$ で $4.9{ }^{\circ} \mathrm{C} 、 1.0 \%$ で $5.6{ }^{\circ} \mathrm{C} 、 3.0 \%$ で $6.2{ }^{\circ} \mathrm{C}$ であり、 濃度が高いほど大きくなる。

冷却最低温度がスケーリング温度と凝固点の間の温度 域の場合、 $\mathrm{NaCl}$ 水溶液は凝固点以下であるため溶液の 凍結は起こるが、スケーリング温度よりも温度が高いた めスケーリングは発生しない。冷却最低温度が $-7{ }^{\circ} \mathrm{C} の$ 場合、濃度が 0.1 1.0 \%ではスケーリングが発生する が、濃度 3.0 \%ではスケーリングが発生せず、同じ冷却 最低温度で凍結しても、スケーリング発生の有無が明確 にわかれる。凍結防止剤は凝固点降下により積雪を融解 させるため、 $\mathrm{NaCl}$ と異なる凍結防止剤においても $\mathrm{NaCl}$ と同様にスケーリング温度が存在すると考えられる。

\section{2 凍結防止剂の濃度によるスケーリング温度の変化 のメカニズムについての考察}

小片凍結融解試験の結果よりスケーリングは、 $\mathrm{NaCl}$ 水溶液の濃度と冷却最低温度との関係により発生の有無 がわかれることがわかった。このことについて、真水で はスケーリングが発生しないことと合わせ、凍結防止剤 水溶液の凍結過程から検討する。スケーリング温度は、 凝固点より 5〜 $6{ }^{\circ} \mathrm{C}$ 程度低い温度となっている。いかな る現象が生起しているかを考察する。真水を冷却した場 合、 $0{ }^{\circ} \mathrm{C}$ で全体が均一に凍結するため、 $0{ }^{\circ} \mathrm{C}$ 以下の冷却 では水として温度低下する。 $\mathrm{NaCl}$ 水溶液の凍結する過 程は真水と異なるため、Fig. 5 に示す $\mathrm{H}_{2} \mathrm{O}-\mathrm{NaCl}$ の相状 態図 ${ }^{10)}$ の概略図を用いて、凍結過程について説明する。 濃度 $3.0 \%$ の $\mathrm{NaCl}$ 水溶液を冷却した場合、溶液の凝固 点に達した際、溶液中では $\mathrm{NaCl}$ の濃度 (分布)の偏りが 存在し、濃度の低い箇所から水が生成し、凍結が開始す

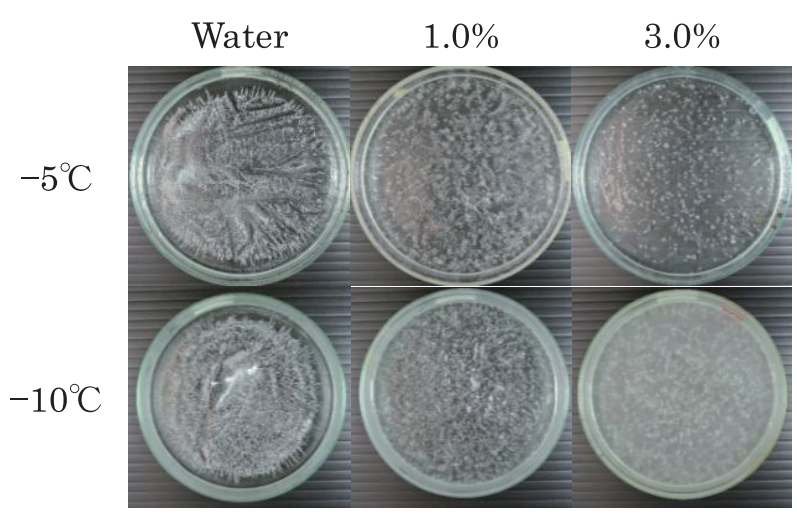

Fig. 6 Observation of freezed water and $\mathrm{NaCl}$ solution

る。溶液の一部が凍結する際では、 $\mathrm{Na}^{+}$及び $\mathrm{Cl}^{-}$を周囲 に排出しながら凍るため、 $\mathrm{NaCl}$ 濃度の低い氷の結晶が生 成される。そのため溶液内の凍結してない液相はその分 $3.0 \%$ ๖も濃度が高くなる。溶液内の凍結していない 液相は濃度が高くなることから、溶液の凝固点がさらに 低下する。凝固点の低下により、さらに低い温度で濃度 の低い水の結晶が生成され、凍結していない液相の濃度 がさらに高くなる。この凍結の繰り返しにより濃度の低 い水の結晶及び濃度の高い $\mathrm{NaCl}$ 水溶液が混在し、水の 結晶が濃度の高い $\mathrm{NaCl}$ 水溶液の周囲を覆うように分布 する。この現象はブラインポケットと呼ばれる。このよ うに $\mathrm{NaCl}$ 水溶液の凍結過程は温度低下に伴い凍結が生 じるため、ある幅を持った温度域において凍結が生じる。

Valenza ${ }^{4)}$ は、ブラインポケットによるソルトスケー リングの劣化メカニズムを提案している。ブラインポ ケットが生じているブラインアイス(塩水水)について、 水晶の細孔を高濃度の $\mathrm{NaCl}$ 水溶液が満たす多孔質な材 料とみなし、 $\mathrm{NaCl}$ 水溶液中の水の結晶割合がブライン アイスの引張強度に関係し、ソルトスケーリングに影響 を与えることを提案している。Valenza らは、 $\mathrm{NaCl}$ 水 溶液の濃度 $3.0 \%$ の場合、 $-10{ }^{\circ} \mathrm{C}$ 以上では溶液中の水 晶の割合が低くスケーリングを起こすほど十分な引張応 カがコンクリート表面に作用しないため、スケーリング は発生しないと示している。本研究の $\mathrm{NaCl}$ 水溶液の濃 度 $3.0 \%$ の場合、 $-9{ }^{\circ} \mathrm{C}$ 以下でスケーリングが生じて おりValenza らの見解と異なる。 $\mathrm{NaCl}$ 水溶液の凝固点 付近ではスケーリングは発生せず、凝固点よりも低温域 でスケーリングが発生するということについては、本 研究の結果とValenza らの見解とは符合している。こ のことより凝固点とスケーリング温度との差は、溶液内 の水晶割合がスケーリング温度に関係していると推定す る。 $\mathrm{NaCl}$ 水溶液の濃度が異なると同じ冷却最低温度で も溶液の水晶割合が異なり、スケーリングの発生の有無 が分かれる。そのため $\mathrm{NaCl}$ 水溶液の濃度の違いにより スケーリング温度が異なる。

Fig. 6 に $\mathrm{NaCl}$ 水溶液の凍結状態についての観察を示 す。真水及び $\mathrm{NaCl}$ 水溶液の濃度 1.0 及び $3.0 \%$ をシャー レに入れ、 $-5{ }^{\circ} \mathrm{C}$ 及び $-10{ }^{\circ} \mathrm{C}$ で小片凍結融解試験の凍 
結時間の 16 時間で凍結を行い観察した。真水の場合、 氷の表面が隆起しており、凍結時の膨張によるものだと 考えられる。凍結防止剤の場合、表面の隆起は起こって おらず、表面の一部に未凍結の溶液が存在しており、未 凍結の溶液の量は $3.0 \%$ \% $5{ }^{\circ} \mathrm{C}$ が多い。水の色に注 目すると、真水の場合は透明度が高い。一方、凍結の防 止剤溶液は温度が低いほど白色になり、3.0\%において $-5{ }^{\circ} \mathrm{C}$ と $-10{ }^{\circ} \mathrm{C}$ 差が明確である。 $\mathrm{NaCl}$ 水溶液のみ白 色になることから、白色になるのはブラインポケット現

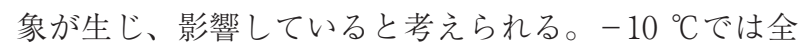
体が凍結し、白色を呈していると考えられる。

詳細なスケーリングメカニズムの解明のためには、ス ケーリング温度付近での $\mathrm{NaCl}$ 水溶液の凍結時物理学的 挙動についてさらなる検討が必要である。

\section{4. まとめ}

本研究ではスケーリング劣化のメカニズム解明を目的 とし、冷却最低温度がー5〜-10 ${ }^{\circ} \mathrm{C}$ の間において、 $\mathrm{NaCl}$ 水溶液の濃度がスケーリング劣化に与える影響について 検討した。

1） $\mathrm{NaCl}$ 水溶液の濃度によってスケーリングが発生す る温度が異なり、濃度によってスケーリング劣化が 発生する温度の䦔值が存在すると考えられる。この 温度をスケーリング温度と定義した。

2）スケーリング温度は $\mathrm{NaCl}$ 水溶液の凝固点よりも低 く、5〜 $6{ }^{\circ} \mathrm{C}$ 程度低い。スケーリング温度は $\mathrm{NaCl}$ 水溶液の濃度が高いほど低くなる。

3）スケーリング温度は、 $\mathrm{NaCl}$ 水溶液の凍結過程で発 生するブラインポケット現象に影響を受けると考ら れる。

\section{参考文献：}

1) G. J. Verbeck, P. Klieger : Studies of "salt" scal- ing of concrete, Highw. Res. Board. Bull., No. 150, pp. 1-13 (1957)

2) M. Pigeon and R. Pleau : Durability of Concrete in Cold Climates, E\&FN SPON, pp. 11-30 (1995)

3) Jochen Stack and Bernd Witcht（訳者：太田利隆、 佐伯昇)：Dauerhaftigkeit Von Beton、社団法人セ メント協会、p. 180 (1999)

4）赤堀弥生ほか：温度及び塩化物イオン濃度勾配がセ メント硬化体中の凍結挙動に及ぼす影響、コンク リート工学年次論文集、Vol. 29、No. 1、pp. 11971202 (2007)

5) John J. ValenzaII and George W Scherer : Mechanism for Salt Scaling, J. Am. Ceram. Soc., Vol. 89, No. 4, pp. 1161-1179 (2006)

6）庄谷征美ほか：塩化物の影響を受けるコンクリート のスケーリング発生過程における歪み挙動に関す る 2、3 の実験、セメント・コンクリート論文集、 No. 54、pp. 370-375 (2000)

7）羽原俊祐ほか：ソルトスケーリングにおよぼす冷 却最低温度と凍結防止剂濃度及びモルタル配合の 影響、セメント・コンクリート論文集、Vol. 69、 pp. 433-439 (2015)

8）小山田哲也ほか：スケーリング劣化を考慮した新し い凍結融解試験法の検討、コンクリート工学年次論 文集、Vol. 33、No. 1、pp. 935-940（2011）

9）菅野華果ほか：既存スケーリング試験方法に対する 小片凍結融解試験方法の整合性、セメント・コンク リート論文集、Vol. 68、pp. 419-425（2014）

10) G. Westphal et al. : Sodium chloride, Ullmann's Encyclopedia of Industrial Chemistry, Vol. 33, Wiley-VCH Verlag GmbH \& Co. KGaA, pp. 319365 (2000) 


\title{
INFLUENCE OF THE LOWEST FREEZING TEMPERATURE ON SALT SCALING DETERIORATION OF CONCRETE WITH DEICER (SODIUM CHLORIDE), AND SALT SCALING TEMPERATURE
}

Yuto TANAKADATE ${ }^{* 1}$, Shunsuke HANEHARA ${ }^{* 2}$, Tetsuya OYAMADA ${ }^{* 2}$ and Toshiya GAMAN³

*1 IWATE UNIVERSITY, Graduate School Student (4-3-5, Ueda, Morioka-shi, Iwate 020-8551, Japan)

*2 IWATE UNIVERSITY, Faculty of Science and Engineering (4-3-5, Ueda, Morioka-shi, Iwate 020-8551, Japan)

*3 NT CONSUlTANTS CO. LTD, Design Research Department (2-35-28, Takamatsu, Moriokashi, Iwate 020-0114, Japan)

\begin{abstract}
Concrete deterioration due to scaling of surface became harder with increase of scattering deicer (sodium chloride) for concrete road structure. This kind of deterioration is well known as salt scaling of concrete. Our former research showed the salt scaling of concrete is more generated under sodium chloride concentration of $0.1 \%$ to $10 \%$, at the range of -5 to -10 degree centigrade. The salt scaling is never generated over -5 degree centigrade. In this research, the relationship between lowest freezing temperature and concentration of sodium chloride solution are investigated by 1 degree centigrade. Scaling temperature is proposed as the threshold temperature to have deterioration of concrete by salt scaling. Scaling temperature varies with the concentration of sodium chloride solution. In case of thicker sodium chloride solution, scaling temperature becomes lower. Scaling temperature is lower about 6 degrees than the freezing point of sodium chloride solution. Phenomena of freezing of brine water seems to relate salt scaling of concrete deterioration.
\end{abstract}

KEY WORDS : Frost damage, Freeze and thaw, Salt scaling, Deicer, New test method with small sized sample, Lowest temperature of freezing 